\title{
Effects of bupivacaine infiltration for controlling post- tonsillectomy pain: A systematic review and meta-analysis
}

\author{
Juan Wang1, Ning Wang ${ }^{1}$ and Fanghua Gong ${ }^{2 *}$ \\ ${ }^{1}$ Department of ENT \& HN Surgery(III), Hunan Provincial People's Hospital, Changsha, Hunan 410016, P.R. China \\ ${ }^{2}$ Department of Nursing, Hunan Provincial People's Hospital, Changsha, Hunan 410016, P.R. China
}

\begin{abstract}
Objective: In this study, we attempt to address these limitations and provide the current state of evidence evaluating the influence of bupivacaine during a tonsillectomy. To demonstrate the effects of bupivacaine during tonsillectomy on the visual analog scale score, mean operative procedure duration, and the onset of postoperative morbidities.
\end{abstract}

Data source: A systematic identification of literature was performed according to PRISMA guidelines on four academic databases: MEDLINE, Scopus, EMBASE, and CENTRAL.

Review methods: A meta-analysis compared the influence of bupivacaine and normal saline administered during tonsillectomy on the visual analog scale score, duration of the operation and postoperative morbidities.

Results: Out of 1,427 records, 18 articles including 729 participants (mean age: $10.2 \pm 6.7$ years) were included in this review. This systematic review presents a $1 \mathrm{~b}$ level of evidence supporting the use of bupivacaine during tonsillectomy to reduce the amount of perceived level of pain, duration of the operation and postoperative morbidity as compared to normal saline. The meta-analysis reveals beneficial effects for bupivacaine interventions by demonstrating small to large effect reduction on visual analog scale score (Hedge's g: -1.47$)$, mean duration of operative procedure $(-1.35)$, and incidence of postoperative morbidity (-0.23) as compared to placebo groups using normal saline.

Conclusion: The current systematic review and meta-analysis recommend the administration of bupivacaine with tonsillectomy as compared to normal saline. The review reports beneficial effects of bupivacaine's administration as compared to normal saline for reducing the perceived level of pain, duration of operation, and postoperative morbidity.

\section{Introduction}

Tonsillectomy is one of the most commonly performed surgical interventions across the world [1-3]. The procedure is characterized by the complete or partial removal of palatine tonsils primarily to address recurring infections, and inflammation $[4,5]$. Moreover, as the surgical intervention is performed in a highly vascularized zone, the associated trauma with the surgical intervention been reported to cause several complications [6,7]. Firstly, the surgical intervention due to its traumatic nature has been reported to promote a high volume of blood loss during the surgery $[8,9]$. Secondly, subsequent inflammatory response as a result of tissue trauma has been reported to precipitate the accumulation of tissue exudates which results in higher levels of pain and postoperative morbidities [10-12]. Davidoss et al. [13], for instance, reported a higher level of edema within 24 hours of the surgery in the palatopharyngeal, palatoglossal area, and uvula can substantially affect the outcome of healing and promote the onset of postoperative morbidities. The authors further added that tonsillectomy also causes collateral damage to the pharyngeal muscles and exposes nerve endings (tonsillar branch glossopharyngeal, maxillary branch trigeminal and lesser palatine nerve [14] (leading to postoperative morbidities such as severe pain, difficulty in swallowing, difficulty in breathing, vomiting, otalgia and more $[13,15,16]$.

To manage these complications, the use of local anesthetic agents such as bupivacaine has been recommended in the literature $[17,18]$.
Studies have reported that the application of bupivacaine could reduce the onset of postoperative morbidities such as pain because of its ability to block afferent nerve endings by inhibiting voltage-gated $\mathrm{Na}^{+}$channel ${ }^{19}$. Moreover, the anesthetic agent has been reported to act by facilitating the deterioration of synaptic $\mathrm{N}$ methyl $\mathrm{D}$ aspartate receptor current during synaptic transmission $[19,20]$. Bupivacaine has also been reported to pertain to robust anti-inflammatory properties [21,22]. Further Block et al. [21] reported that bupivacaine can reduce inflammatory activity by inhibiting $\mathrm{Ca}^{2+}$ ion signaling, the release of interleukin- $1 \beta$ in astrocytes and by interacting with 5-hydroxytryptamine, opioid, glutamate receptors. Likewise, the ability of bupivacaine to reduce vascular permeability has also been reported to be an additional underlying mechanism due to which intraoperative and postoperative complications are reduced [23,24]. The use of bupivacaine has also been reported over its counterpart anesthetic agents such as lidocaine, ropivacaine due to its higher comparative potency, sustained effects and lower toxicity profile [25-27].

*Correspondence to: Fanghua Gong, Department of Nursing, Hunan Provincial People's Hospital, 69 Jiefang West Road, Changsha, Hunan 410016, P.R. China, Tel: +3124-3616538; E-mail: gongfh_dr@sohu.com

Key words: anesthesia, tonsillectomy, adenotonsillectomy, bupivacaine, pain

Received: May 11, 2020; Accepted: May 29, 2020; Published: June 03, 2020 
Despite the enhanced effectiveness demonstrated by bupivacaine a consensus concerning its application alongside tonsillectomy to reduce intraoperative and postoperative complications is still missing. While on one hand, a part of the literature recommends the administration of bupivacaine during rhinoplasty because of its ability to limit intraoperative and postoperative complications [28-31]. On the other hand, a part of the literature suggests that postoperative morbidities such as pain, vomiting, constipation, otalgia are normal manifestations of tonsillectomy and that the administration of anesthetic agents such as bupivacaine is not necessary [32,33]. This lack of consensus has proven to be a challenging avenue for the surgeons to develop an efficient decision-making model for selecting optimal drug intervention alongside tonsillectomy to reduce intraoperative and postoperative complications. Previous meta-analyses conducted by [18] also provide inconclusive evidence concerning the application of bupivacaine in adjunct with tonsillectomy. Moreover, this review did not explain the isolated efficacy of bupivacaine on the intraoperative factors associated with tonsillectomy such as duration of the operative procedure. In addition to that, since the publication of this meta-analysis, several high-quality, randomized control trials have been published that evaluate the efficacy of bupivacaine on intraoperative and postoperative morbidities associated with tonsillectomy [28,31,34-36].

In this present systematic review and meta-analysis, we aim to further provide a current state of knowledge by evaluating the effects of bupivacaine on operative and postoperative outcomes associated with tonsillectomy. This review will provide comprehensive evidence concerning the mean perceived level of pain score, mean operative procedure duration, and incidence of postoperative morbidities. Such an attempt would be useful in the decision-making process of otolaryngologists to determine the best practice approach to minimize morbidity associated with tonsillectomy procedures.

\section{Methods}

This systematic review and meta-analysis were carried in adherence to PRISMA guidelines [38]. A PRISMA checklist has been provided in the supplementary file 1 .

\section{Data search strategy}

We searched four academic databases (MEDLINE, CENTRAL, EMBASE, and Scopus) from inception until April 2020 using MeSH keywords: "Tonsillectomy", "Bupivacaine", "1-Butyl-N-(2,6dimethylphenyl)-2-piperidinecarboxamide", "Bupivacain janapharm”, "Bupivacain-RPR", "Bupivacaina braun", "Bupivacaine anhydrous", "Bupivacaine carbonate", "Bupivacaine hydrochloride", "Bupivacaine monohydrochloride", "Bupivacaine monohydrate", "Buvacaina", "Carbostesin", "Dolanaest", "Marcain”, "Marcaine”, "Sensorcaine”, "Svedocain sin vasoconstr", "anesthesia", "anesthetics", "visual analog scale", "Children hospital of eastern Ontario pain scale", "morbidity", "complications", "blood loss", and "postoperative morbidity". Besides, we screened the bibliography of the included studies for any additional relevant study. The inclusion criteria for the included studies were as follows:

a) Studies evaluated the effects of bupivacaine on morbidity and mortality related factors in patients with chronic obstructive pulmonary disease.

b) Studies evaluated the outcome(s) of the mean duration of hospital stay, hospital-related costs, existing co-morbidities, survival duration, survival rate, mortality rate amongst chronic obstructive pulmonary disease patients with/without anemia. c) Studies evaluated and reported outcomes in a postoperative followup assessment.

d) Studies were either randomized controlled trials, quasi-randomized controlled trials, controlled clinical trials, prospective observational trials with control groups or retrospective trials.

e) Studies published in peer-reviewed scientific journals, conferences.

f) Studies published in the English language.

The selection procedure was independently replicated by two reviewers to avoid biasing. The following data were extracted from the included studies: authors, sample description (gender, age), assessed variable, country of research, follow-up duration, and outcome measures. In the articles where quantitative data outcomes were incomplete or not mentioned the reviewers made attempts to contact respective corresponding authors for additional data.

\section{Quality assessment}

The risk of bias in the included studies was assessed by Cochrane risk of bias assessment tool for randomized controlled trials [38]. The included studies were independently appraised by two reviewers. Inadequate randomization, concealment of allocation and reporting of selective outcomes were considered as major threats for biasing [39]. In cases of ambiguity, discussions were held between the reviewers until a consensus was reached. Moreover, a level of evidence analysis based on the center for evidence-based medicine was also included [40].

\section{Data analysis}

A within-group meta-analysis of the included studies was carried out using CMA (Comprehensive Meta-analysis version 2.0) [41]. The data was distributed and separately analyzed for the mean edema scores, mean ecchymosis score and the amount of intraoperative blood loss. An additional analysis was carried to compare the mean edema and ecchymosis scores after a week of rhinoplasty. A meta-analysis was conducted based on the random-effects model [42]. The effect sizes are reported as weighted Hedge's g. The thresholds for interpreting the weighted effect sizes are: $\leq 0.2$ a small effect, $\leq 0.5$ as a medium effect and $\geq 0.8$ a large effect [43]. Heterogeneity was assessed by computing $\mathrm{I}^{2}$ statistics. The thresholds for interpreting heterogeneity are: $0-25 \%$ with negligible heterogeneity, $25 \%-75 \%$ with moderate heterogeneity and $\geq 75 \%$ with substantial heterogeneity [44]. Sensitivity analyses were performed in cases where substantial sources of heterogeneity existed [45]. Here, based on the presence or absence of inadequate randomization methods in the studies we either included or excluded the results of the studies. For each evaluated parameter details of weighted effect size, 95\% confidence intervals, level of significance and heterogeneity have been duly reported. Besides, we analyzed publication bias by performing Duval and Tweedie's trim and fill procedure [46]. This non-parametric method estimates the number of missing studies that might exist and the effects they might have on the outcome of a meta-analysis. Here, asymmetric studies are imputed from the left side of the plotted graph to identify the unbiased effect. Thereafter, these trimmed effects are refilled in the plotted graph and then the combined effect is recalculated. In the present review, the alpha level was set at $5 \%$.

\section{Results}

A preliminary search on four academic databases resulted in a total of 1,417 studies, 10 more studies were included after the bibliography of these articles were screened (Figure 1). Thereafter, upon excluding 


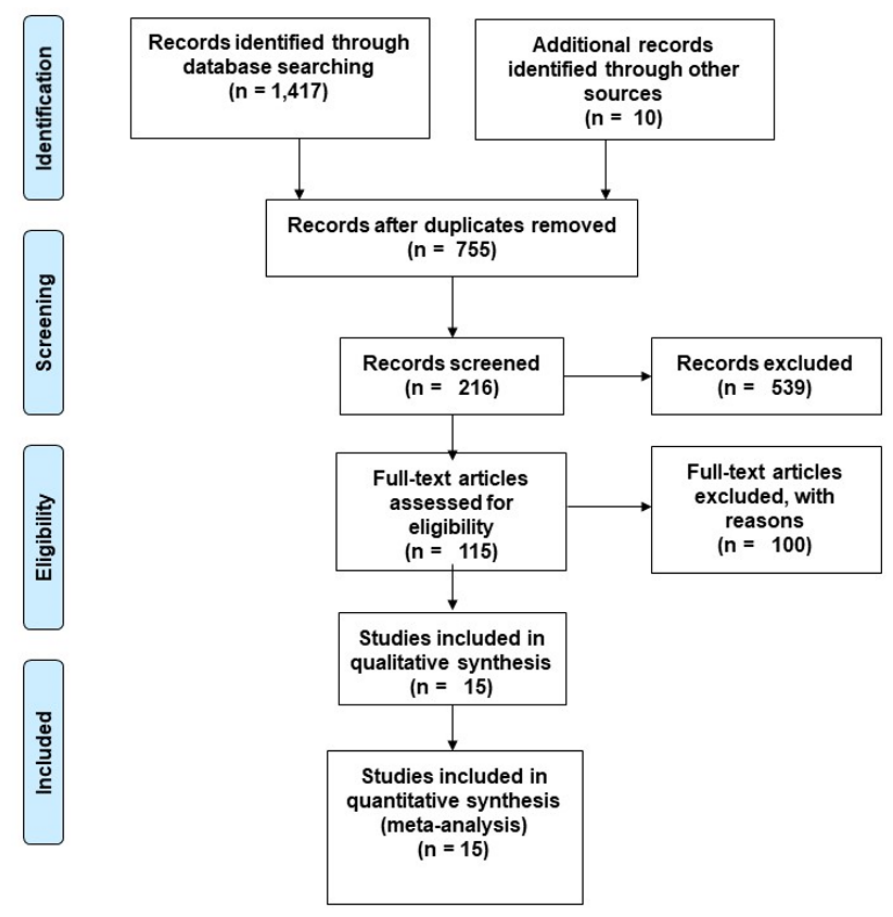

Figure 1. Illustrates the PRISMA flow chart for the included studies.

the duplicates and applying the inclusion criteria, a total of 14 studies were retained. Here, all 15 of the included studies were randomized controlled trials [17,28-32,34-36,47-52].

All 15 of the included studies had compared the efficacy between bupivacaine and normal saline on the perceived level of pain after tonsillectomy $[14,17,28,32,34-36,47,48,50-52]$. Here, 12 of the included studies had evaluated the perceived level of pain with visual analog scale score [17,28-31,34-36,48-52], whereas two had evaluated the perceived level of pain with the Children hospital of eastern Ontario pain scale $[31,47]$. Nine of the included studies reported a significant $(\mathrm{p}<0.05)$ reduction [17,28-31,34-36,47], and two studies reported a $(\mathrm{p}>0.05)$ reduction [32,50], in the perceived level of pain for patients receiving bupivacaine as compared to normal saline during tonsillectomy. Three studies reported no differences in the perceived level of pain between the groups receiving bupivacaine and normal saline [58,51,52]. Furthermore, five of the included studies had reported the incidence of postoperative morbidity after tonsillectomy in between groups receiving bupivacaine and normal saline $[32,34,35,47,50]$. Here, three of the included studies reported a significant $(\mathrm{p}<0.05)$ reduction , and one reported a ( $\mathrm{p}>0.05)$ reduction [34], in the onset of post-tonsillectomy morbidity in patients receiving bupivacaine as compared to the placebo group $[35,47,50]$. One study reported an $(p>0.05)$ increase in the onset of post-tonsillectomy morbidity in patients receiving bupivacaine as compared to the placebo group [32]. Finally, four of the included studies had compared the efficacy between bupivacaine and normal saline on the mean duration of tonsillectomy procedure [17,29,31,36]. Here, all of the included studies reported a significant reduction in the mean duration of tonsillectomy procedure for the group receiving bupivacaine as compared to the placebo group.

\section{Risk of bias}

The risk of bias for the randomized controlled trials according to Cochrane's risk of bias assessment tool has been demonstrated in table 1 and figure 2 . The overall risk in the included studies is low.
The highest risk of bias was observed to be due to selective reporting and inadequate blinding of outcome in the included studies. A level of evidence of $1 \mathrm{~b}$ was observed for all the included studies based on their experimental design.

\section{Publication bias}

The trim and fill procedure identified no missing studies on either side of the mean effect (Figure 3). Further, according to the randomeffect model, the point estimates and $95 \%$ confidence intervals for the evaluated parameters are $-1.44(-1.95$ to -0.93$)$. According to the trim and fill procedure report, these values are unchanged.

\section{Participant information}

A total of 710 patients (Table 2) were evaluated in the studies included in this review. Here, a total of 379 (122 females, 167 males) patients were in the group receiving bupivacaine during a tonsillectomy, whereas 331 (130 females, 141 males) patients were in the placebo receiving normal saline during a tonsillectomy. Two studies did not define their gender distribution $[28,30]$.

The overall age of the patients was $9.1 \pm 5.6$ years. In the group where the patients received bupivacaine during a tonsillectomy, the age of the patients was $9.1 \pm 6.4$ years, whereas in the placebo group the average age of the patients was $8.8 \pm 4.9$ years. Two studies reported an overall age of their sample $[28,30]$.

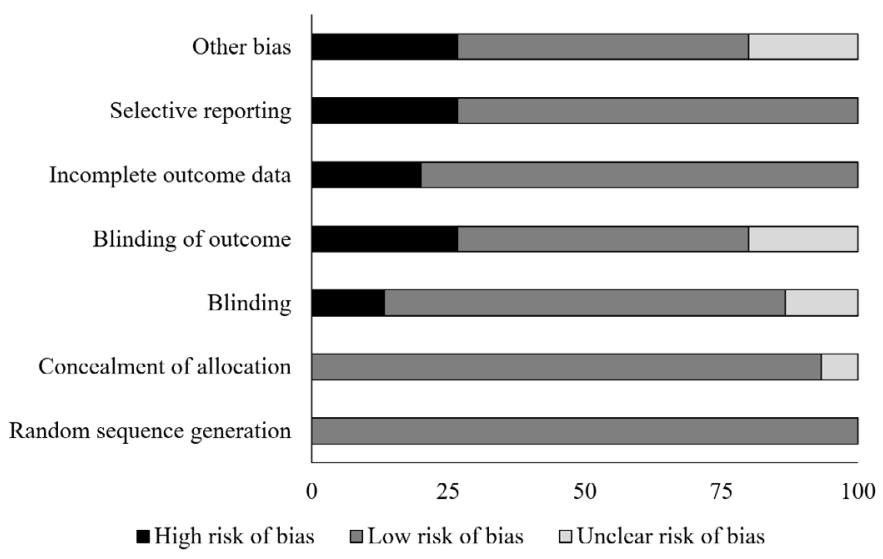

Figure 2. Illustrates the risk of bias (\%) within studies according to Cochrane risk of bias assessment tool for randomized controlled trials.

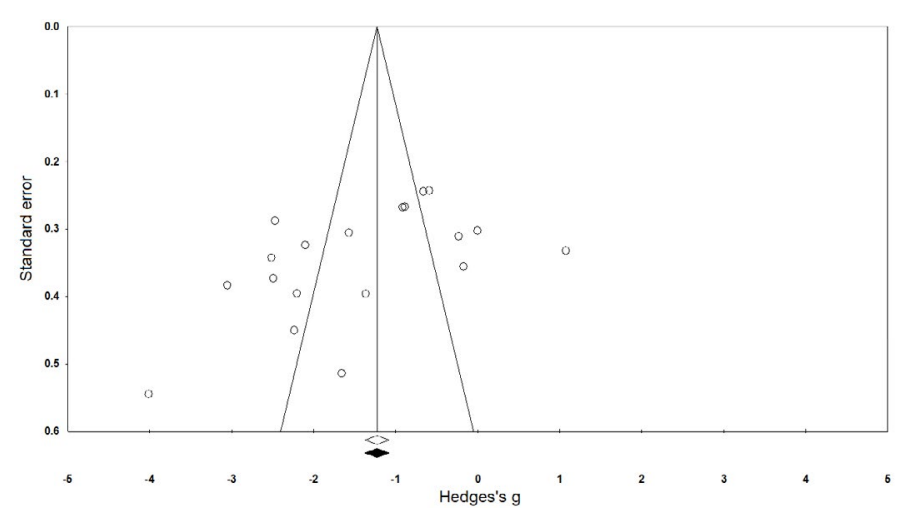

Figure 3. Illustrates the publication bias funnel plot by the Duval \& Tweedie trim and fill procedure. Each of the analyzed effects is denoted by a circle in the plot. The boundaries of the plot mark the area where $95 \%$ of all the effects reside in case there were no publication biases. The vertical midline denotes the mean standardized effect of zero. 
Table 1. Illustrates the quality of the analyzed studies according to the Cochrane risk of bias assessment tool for randomized controlled trials (-: high risk of bias, +: low risk of bias, ? unclear risk of bias.

\begin{tabular}{|c|c|c|c|c|c|c|c|c|}
\hline Study & $\begin{array}{c}\text { Random sequence } \\
\text { generation }\end{array}$ & $\begin{array}{l}\text { Concealment of } \\
\text { allocation }\end{array}$ & Blinding & $\begin{array}{l}\text { Blinding of } \\
\text { outcome }\end{array}$ & $\begin{array}{c}\text { Incomplete } \\
\text { outcome data }\end{array}$ & $\begin{array}{l}\text { Selective } \\
\text { reporting }\end{array}$ & Other bias & Level of evidence \\
\hline Junaid et al. [28] & + & + & + & $?$ & - & + & - & $1 \mathrm{~b}$ \\
\hline Abdel et al. [1] & + & + & - & - & + & + & - & $1 \mathrm{~b}$ \\
\hline Tuhanioglu et al. [57] & + & + & + & + & - & - & $?$ & $1 \mathrm{~b}$ \\
\hline Haksever et al. [20] & + & + & + & + & + & + & + & $1 \mathrm{~b}$ \\
\hline Ergil et al. [18] & + & + & + & + & + & + & + & $1 \mathrm{~b}$ \\
\hline Özkiriş et al. [44] & + & + & $?$ & - & + & + & + & $1 \mathrm{~b}$ \\
\hline Özmen et al. [45] & + & + & + & + & + & + & + & $1 \mathrm{~b}$ \\
\hline Nikandish et al. [41] & + & + & + & + & + & + & + & $1 \mathrm{~b}$ \\
\hline Karaaslan et al. [29] & + & + & + & - & + & + & + & $1 \mathrm{~b}$ \\
\hline Unal et al. [58] & + & + & + & + & + & - & $?$ & $1 \mathrm{~b}$ \\
\hline Akoglu et al. [2] & + & + & + & $?$ & + & + & + & $1 \mathrm{~b}$ \\
\hline Kaygusuz et al. [31] & + & + & - & - & + & + & - & $1 \mathrm{~b}$ \\
\hline Johansen et al. [25] & + & + & + & + & + & + & - & $1 \mathrm{~b}$ \\
\hline Stuart et al. [54] & + & + & + & + & + & - & + & $1 \mathrm{~b}$ \\
\hline Jebeles et al. [24] & + & $?$ & $?$ & $?$ & - & - & $?$ & $1 \mathrm{~b}$ \\
\hline
\end{tabular}

Table 2. Illustrates the characteristics of the included studies. BP: Bupivacaine, NS: Normal saline, F: Female, M: Male

\begin{tabular}{|c|c|c|c|c|c|c|}
\hline Author & $\begin{array}{l}\text { Age: } \mathbf{M} \pm \text { S.D } \\
\text { years }\end{array}$ & Sample size & Country & Assessment & Follow-up (hours) & Outcome \\
\hline Junaid et al. [28] & $\begin{array}{l}14.5 \pm 7.4 \\
\text { BP: - } \\
\text { NS: - }\end{array}$ & $\begin{array}{l}180(83 \mathrm{~F}, 97 \mathrm{M}) \\
\text { BP: } 60(\mathrm{~F}, \mathrm{M}) \\
\text { NS: } 30(\mathrm{~F}, \mathrm{M})\end{array}$ & Pakistan & Visual analog scale & $4,8,12,16$ & $\begin{array}{l}\text { Significant reduction in visual analog scale } \\
\text { score in BP as compared to NS. }\end{array}$ \\
\hline Abdel et al. [1] & $\begin{array}{l}8.7 \\
\text { BP: - } \\
\text { NS: - }\end{array}$ & $\begin{array}{l}60(31 \mathrm{~F}, 29 \mathrm{M}) \\
\text { BP: } 30(\mathrm{~F}, \mathrm{M}) \\
\text { NS: } 30(\mathrm{~F}, \mathrm{M})\end{array}$ & Egypt & Visual analog scale & $1,4,8,24$ & $\begin{array}{l}\text { Significant reduction in visual analog scale } \\
\text { score in BP as compared to NS. }\end{array}$ \\
\hline Tuhanioglu et al. [57] & $\begin{array}{l}\text { BP: } 30 \pm 6 \\
\text { NS: } 25 \pm 6\end{array}$ & $\begin{array}{l}\text { BP: } 15(9 \mathrm{~F}, 6 \mathrm{M}) \\
\text { NS: } 15(8 \mathrm{~F}, 7 \mathrm{M})\end{array}$ & Pakistan & $\begin{array}{l}\text { Visual analog scale, operating } \\
\text { time }\end{array}$ & $0.25,6,12,24,168$ & $\begin{array}{l}\text { Significant reduction in visual analog scale } \\
\text { score, operating time in BP as compared } \\
\text { to NS. }\end{array}$ \\
\hline Haksever et al. [20] & $\begin{array}{l}\text { BP: } 6 \pm 2.9 \\
\text { NS: } 6.7 \pm 3.6\end{array}$ & $\begin{array}{l}\text { BP: } 40(20 \mathrm{~F}, 20 \mathrm{M}) \\
\text { NS: } 20(10 \mathrm{~F}, 10 \mathrm{M})\end{array}$ & Turkey & $\begin{array}{l}\text { Visual analog scale, postoperative } \\
\text { morbidity }\end{array}$ & $\begin{array}{l}1,5,13,17,21,24,48 \\
72,96,120,144\end{array}$ & $\begin{array}{l}\text { Significant reduction in visual analog scale } \\
\text { score in BP as compared to NS. } \\
\text { Reduced morbidities associated in BP as } \\
\text { compared to NS. }\end{array}$ \\
\hline Ergil et al. [18] & $\begin{array}{l}\text { BP: } 6 \pm 2 \\
\text { NS: } 6 \pm 2\end{array}$ & $\begin{array}{l}\text { BP: } 30(14 \mathrm{~F}, 16 \mathrm{M}) \\
\text { NS: } 30(15 \mathrm{~F}, 15 \mathrm{M})\end{array}$ & Turkey & $\begin{array}{l}\text { Visual analog scale, operation } \\
\text { duration }\end{array}$ & $0,0.15,0.5,6,12,24$ & $\begin{array}{l}\text { Significant reduction in visual analog scale, } \\
\text { operating time score in BP as compared } \\
\text { to NS. }\end{array}$ \\
\hline Özkiriş et al. [44] & $\begin{array}{l}\text { BP: } 8.1 \pm 4.2 \\
\text { NS: } 8.1 \pm 4.2\end{array}$ & $\begin{array}{l}\text { BP: } 29(13 \mathrm{~F}, 16 \mathrm{M}) \\
\text { NS: } 29(12 \mathrm{~F}, 17 \mathrm{M})\end{array}$ & Turkey & $\begin{array}{l}\text { Visual analog scale, operation } \\
\text { duration }\end{array}$ & $\begin{array}{l}1,4,8,16,24,48,72,96 \\
120,144,168\end{array}$ & $\begin{array}{l}\text { Significant reduction in visual analog scale, } \\
\text { operating time score in BP as compared } \\
\text { to NS. }\end{array}$ \\
\hline Özmen et al. [45] & $\begin{array}{l}\text { BP: } 6 \pm 3.7 \\
\text { NS: } 6.7 \pm 3.6\end{array}$ & $\begin{array}{l}\text { BP: } 20(10 \mathrm{~F}, 10 \mathrm{M}) \\
\text { NS: } 20(11 \mathrm{~F}, 9 \mathrm{M})\end{array}$ & Turkey & $\begin{array}{l}\text { Visual analog scale, postoperative } \\
\text { morbidity }\end{array}$ & $\begin{array}{l}1,5,13,17,21,24,48 \\
72,96,120,144\end{array}$ & $\begin{array}{l}\text { Significant reduction in visual analog scale } \\
\text { score and co-morbidities in BP as compared } \\
\text { to NS. }\end{array}$ \\
\hline Nikandish et al. [41] & $\begin{array}{l}\text { BP: } 10 \pm 2.4 \\
\text { NS: } 10 \pm 2.3\end{array}$ & $\begin{array}{l}\text { BP: } 33(14 \mathrm{~F}, 19 \mathrm{M}) \\
\text { NS: } 36(17 \mathrm{~F}, 19 \mathrm{M})\end{array}$ & Iran & $\begin{array}{l}\text { Visual analog scale, operation } \\
\text { duration }\end{array}$ & $1,2,4,6,8,12$ & $\begin{array}{l}\text { Significant reduction in visual analog scale, } \\
\text { operating time score in BP as compared } \\
\text { to NS. }\end{array}$ \\
\hline Karaaslan et al. [29] & $\begin{array}{l}\text { BP: } 7 \pm 0.5 \\
\text { NS: } 7.4 \pm 0.5\end{array}$ & $\begin{array}{l}\text { BP: } 25(11 \mathrm{~F}, 14 \mathrm{M}) \\
\text { NS: } 25(17 \mathrm{~F}, 8 \mathrm{M})\end{array}$ & Turkey & $\begin{array}{l}\text { Children hospital of eastern } \\
\text { Ontario pain scale, postoperative } \\
\text { morbidity }\end{array}$ & $0.25,1,4,8,16,24$ & $\begin{array}{l}\text { Reduction in Children hospital of eastern } \\
\text { Ontario pain scale score in BP as compared } \\
\text { to NS. } \\
\text { Increased co-morbidities in BP as compared } \\
\text { to NS. }\end{array}$ \\
\hline Unal et al. [58] & $\begin{array}{l}\text { BP: } 7.5 \pm 3.1 \\
\text { NS: } 8.2 \pm 2.9\end{array}$ & $\begin{array}{l}\text { BP: } 20(2 \mathrm{~F}, 18 \mathrm{M}) \\
\text { NS: } 20(4 \mathrm{~F}, 16 \mathrm{M})\end{array}$ & Turkey & Visual analog scale & $\begin{array}{l}0,0.08,0.16,0.25,0.5,1 \\
2,6,12,24\end{array}$ & $\begin{array}{l}\text { No difference in visual analog scale score } \\
\text { between BP and NS. }\end{array}$ \\
\hline Akoglu et al. [2] & $\begin{array}{l}\text { BP: } 6 \pm 2.5 \\
\text { NS: } 6.1 \pm 1.6\end{array}$ & $\begin{array}{l}\text { BP: } 16(6 \mathrm{~F}, 10 \mathrm{M}) \\
\text { NS: } 15(6 \mathrm{~F}, 9 \mathrm{M})\end{array}$ & Turkey & $\begin{array}{l}\text { Children hospital of eastern } \\
\text { Ontario pain scale, postoperative } \\
\text { morbidity }\end{array}$ & $0.25,1,4,12,16,24$ & $\begin{array}{l}\text { Significant reduction in Children hospital } \\
\text { of eastern Ontario pain scale score and co- } \\
\text { morbidities in BP as compared to NS. }\end{array}$ \\
\hline Kaygusuz et al. [31] & $\begin{array}{l}\text { BP: } 9 \pm 2.7 \\
\text { NS: } 8 \pm 2.6\end{array}$ & $\begin{array}{l}\text { BP: } 20(7 \mathrm{~F}, 13 \mathrm{M}) \\
\text { NS: } 20(9 \mathrm{~F}, 11 \mathrm{M})\end{array}$ & Turkey & $\begin{array}{l}\text { Visual analog scale, postoperative } \\
\text { morbidity }\end{array}$ & $1,3,7$ & $\begin{array}{l}\text { Reduction in visual analog scale and co- } \\
\text { morbidities in BP as compared to NS. }\end{array}$ \\
\hline Johansen et al. [25] & $\begin{array}{l}\text { BP: } 25 \\
\text { NS: } 23\end{array}$ & $\begin{array}{l}\text { BP: } 9(5 \mathrm{~F}, 4 \mathrm{M}) \\
\text { NS: } 10(6 \mathrm{~F}, 4 \mathrm{M})\end{array}$ & Denmark & Visual analog scale & $\begin{array}{l}0,24,48,72,96,120 \\
144,168,192,226,240\end{array}$ & $\begin{array}{l}\text { Significant reduction in visual analog scale } \\
\text { score in BP as compared to NS. }\end{array}$ \\
\hline Stuart et al. [54] & $\begin{array}{l}\text { BP: } 6.4 \\
\text { NS: } 6\end{array}$ & $\begin{array}{l}\text { BP: } 21(9 \mathrm{~F}, 12 \mathrm{M}) \\
\text { NS: } 21(12 \mathrm{~F}, 9 \mathrm{M})\end{array}$ & United Kingdom & Visual analog scale & $0,0.16,1,4,24$ & $\begin{array}{l}\text { No difference in visual analog scale score } \\
\text { between BP and NS. }\end{array}$ \\
\hline Jebeles et al. [24] & $\begin{array}{l}\text { BP: } 7.5 \pm 3.1 \\
\text { NS: } 8.2 \pm 2.9\end{array}$ & $\begin{array}{l}\text { BP: } 20(7 \mathrm{~F}, 13 \mathrm{M}) \\
\text { NS: } 20(9 \mathrm{~F}, 11 \mathrm{M})\end{array}$ & USA & Visual analog scale & $0,24,48,72,96,120$ & $\begin{array}{l}\text { No difference in visual analog scale score } \\
\text { between BP and NS. }\end{array}$ \\
\hline
\end{tabular}




\section{Visual analog scale}

Fifteen of the included studies had compared the effects between bupivacaine and placebo receiving normal saline on the perceived levels of pain for patients receiving tonsillectomy [17,28-32,34-36,4752]. An across group, random-effect analysis (Figure 4) revealed a large negative and non-significant effect of bupivacaine for reducing the perceived level of pain post a tonsillectomy as compared to the placebo group (g: $-1.47,95 \%$ C.I: -2.07 to -0.87 , p <0.01) with negligible heterogeneity ( $\left.I^{2}: 14.8 \%\right)$.

\section{Duration of operation}

Four studies had compared the effects between bupivacaine and placebo receiving normal saline on the mean duration of tonsillectomy procedure [17,29,31,36]. An across group, random-effect analysis (Figure 5) revealed a large negative and significant effect of bupivacaine for reducing the mean duration of tonsillectomy procedure as compared to the placebo group (g: $-1.35,95 \%$ C.I: -2.44 to $-0.26, \mathrm{p}=0.01$ ) with negligible heterogeneity $\left(\mathrm{I}^{2}: 6.4 \%\right)$.

\section{Postoperative co-morbidity}

Five studies had compared the effects between bupivacaine and placebo receiving normal saline on postoperative morbidities for patients receiving tonsillectomy $[32,34,35,47,50]$. An across group, random-effect analysis (Figure 6) revealed a small negative and non-significant effect of bupivacaine for reducing the postoperative morbidity post a tonsillectomy as compared to the placebo group (g: $-0.23,95 \%$ C.I: -0.65 to $0.19, p=0.2$ ) with no heterogeneity (I': $0 \%)$.

\section{Discussion and conclusion}

This review provides a comprehensive state of evidence concerning the outcome of intraoperative and postoperative morbidities associated with tonsillectomy with the administration of bupivacaine. A beneficial effect of bupivacaine's application with tonsillectomy to reduce the perceived level of pain, mean operational duration and postoperative morbidities was observed in this present systematic review. Here, 13 out of 15 studies included in our review, confirm a significant reduction in perceived level of pain, duration of the operation and postoperative morbidities when bupivacaine was administered during tonsillectomy as compared to normal saline.

Due to the complex organization of the pharyngeal segments and its vasculature, tonsillectomy presents itself with a challenging avenue for otolaryngologists across the world [53,54]. The traumatic nature of the procedure increases the likelihood of a patient to experience widespread intraoperative and postoperative morbidities $[18,30,31,35]$. To counteract these morbidities, the use of bupivacaine as an adjunct has been increasingly recommended because of its superior antinociceptive properties and its ability to reduce vascular permeability and inflammation [22-24,49]. Babst et al. [55] suggested that bupivacaine pertains a high affinity towards the neural tissue and that the agent acts by inhibiting the onset of an action potential by obstructing the $\mathrm{Na}^{+}$ion transmission through the neural membrane. The authors also reported that the ability of bupivacaine to bind with $\mathrm{Ca}^{2+}$ ion sites in the external layer of the lipid to cause additional interference in the mobility of phosphate groups, which in turn inhibits the generation of action potential [55]. Moreover, studies have suggested that the ability of bupivacaine to reduce vascular permeability, and vasodilation to be additional reasons due to which it might be able to subside postoperative morbidities associated with tonsillectomy $[56,57]$. In agreement with these observations, the studies included in this systematic review too reported that the adjunct administration of bupivacaine with tonsillectomy resulted in a significant reduction in postoperative morbidities. For instance, Haksever et al. [34] compared the effects of adjunct administration of $0.5 \%$ topical bupivacaine

\section{Study name}

\begin{tabular}{|c|c|c|c|c|c|c|c|}
\hline & $\begin{array}{l}\text { Hedges's } \\
\mathrm{g}\end{array}$ & $\begin{array}{l}\text { Standard } \\
\text { error }\end{array}$ & Variance & $\begin{array}{c}\text { Lower } \\
\text { limit }\end{array}$ & $\begin{array}{c}\text { Upper } \\
\text { limit }\end{array}$ & Z-Value & $\mathrm{p}$-Value \\
\hline Junaid et al. (2020) & -2.469 & 0.288 & 0.083 & -3.034 & -1.904 & -8.570 & 0.000 \\
\hline Abdel and Farouk (2019) & -0.887 & 0.267 & 0.071 & -1.411 & -0.363 & -3.316 & 0.001 \\
\hline Tuhanioglu and Erkan (2018) & -1.362 & 0.396 & 0.157 & -2139 & -0.585 & -3.436 & 0.001 \\
\hline Haksever et al. (2014) & -1.568 & 0.306 & 0.094 & -2168 & -0.969 & -5.127 & 0.000 \\
\hline Ergil et al. (2012) & -0.915 & 0.268 & 0.072 & -1.440 & -0.389 & -3.411 & 0.001 \\
\hline Özkins et al. (2012) & -3.050 & 0.384 & 0.147 & -3.803 & -2298 & -7.947 & 0.000 \\
\hline Özmen and Özmen (2011) & -2.203 & 0.396 & 0.157 & -2979 & -1.427 & -5.565 & 0.000 \\
\hline Nikandish et al. (2008) & -0.660 & 0.245 & 0.060 & -1.140 & -0.180 & -2.695 & 0.007 \\
\hline Karaaslan et al. (2008) & -2.490 & 0.374 & 0.140 & -3.222 & -1.758 & -6.667 & 0.000 \\
\hline Unal et al. (2007) & 1.078 & 0.333 & 0.111 & 0.426 & 1.730 & 3.242 & 0.001 \\
\hline Akoglu et al. (2006) & -2.235 & 0.451 & 0.203 & -3.118 & -1.352 & -4.959 & 0.000 \\
\hline Kaygustz et al. (2003) & -0.230 & 0.311 & 0.097 & -0.840 & 0.379 & -0.740 & 0.459 \\
\hline Johansen et d. (1996) & -1.656 & 0.515 & 0.265 & -2664 & -0.647 & -3.218 & 0.001 \\
\hline Stuart et al. (1994) & 0.000 & 0.303 & 0.092 & -0.593 & 0.593 & 0.000 & 1.000 \\
\hline \multirow[t]{2}{*}{ Jebeles et al. (1992) } & -4.010 & 0.545 & 0.297 & -5.078 & -2941 & -7.357 & 0.000 \\
\hline & -1.476 & 0.307 & 0.094 & -2077 & -0.874 & -4.807 & 0.000 \\
\hline
\end{tabular}

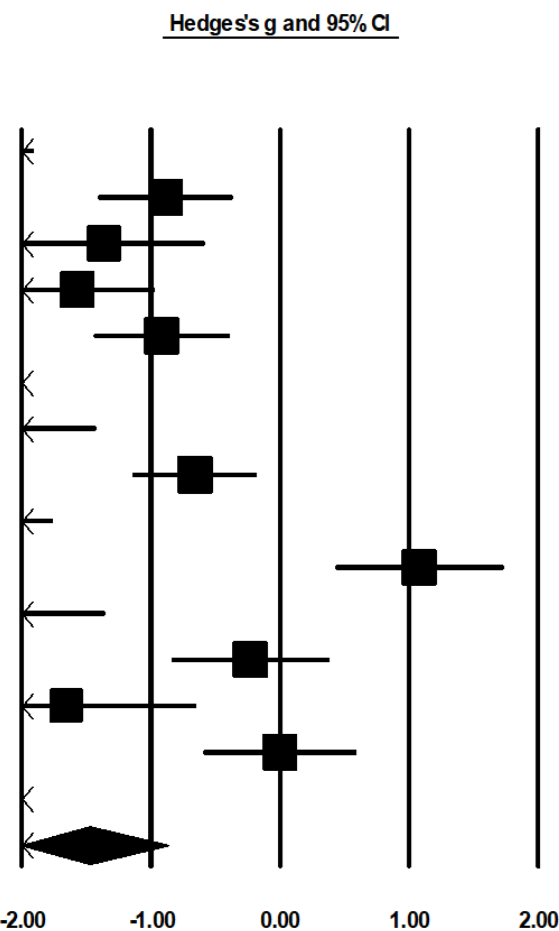

Figure 4. Illustrates the forest plot for studies evaluating the perceived level of pain between groups receiving bupivacaine and normal saline 24 hours post-tonsillectomy. Weighted effect size is presented as boxes, $95 \%$ C.I are presented as whiskers. A negative effect represents a reduction in the perceived level of pain for patients receiving bupivacaine during a tonsillectomy; a positive effect represents a reduction in the perceived level of pain for patients in the placebo group receiving normal saline during a tonsillectomy. 


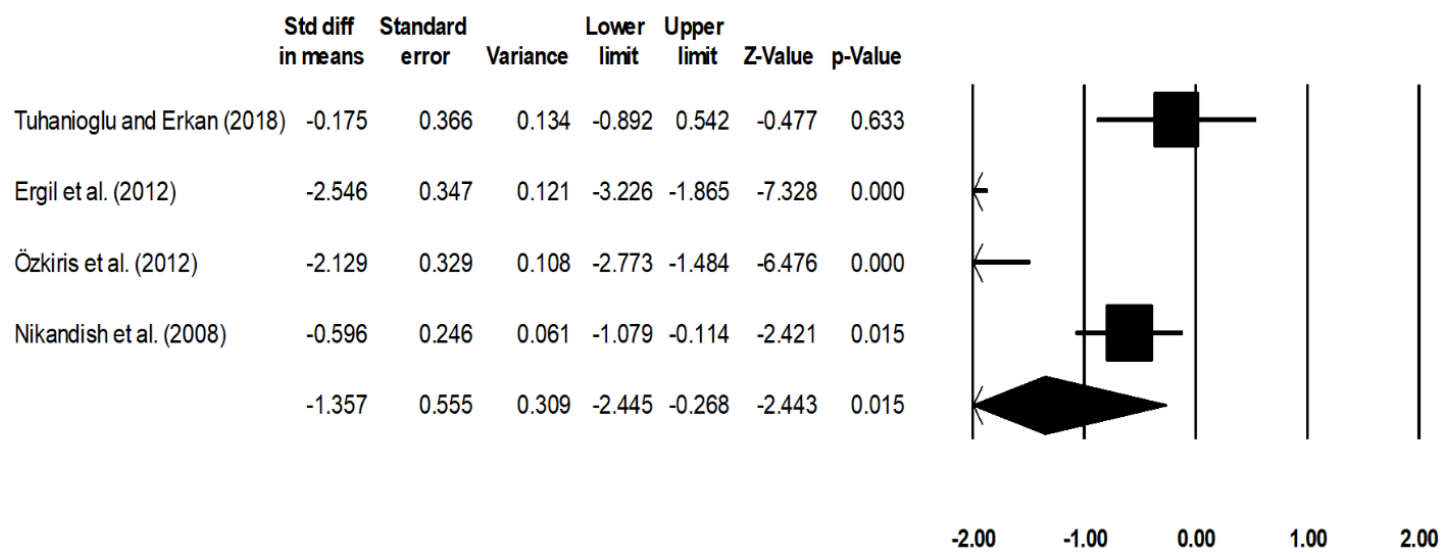

Figure 5. Illustrates the forest plot for studies evaluating the mean duration of tonsillectomy procedure between groups receiving bupivacaine and normal saline. Weighted effect size is presented as boxes, $95 \%$ C.I are presented as whiskers. A negative effect represents a reduced duration of tonsillectomy procedure for patients receiving bupivacaine; a positive effect represents a reduced duration of a tonsillectomy procedure for patients in the placebo group receiving normal saline.

\begin{tabular}{|c|c|c|c|c|c|c|c|}
\hline \multirow[t]{2}{*}{ Study name } & \multicolumn{7}{|c|}{ Statistics for each study } \\
\hline & $\begin{array}{l}\text { Hedges's } \\
\text { g }\end{array}$ & $\begin{array}{l}\text { Standard } \\
\text { error }\end{array}$ & Variance & $\begin{array}{c}\text { Lower } \\
\text { limit }\end{array}$ & $\begin{array}{c}\text { Upper } \\
\text { limit }\end{array}$ & Z-Value & p-Value \\
\hline Haksever et al. (2014) & -0.558 & 0.307 & 0.094 & -1.159 & 0.044 & -1.816 & 0.069 \\
\hline Özmen and Özmen (2011) & -0.749 & 0.387 & 0.150 & -1.507 & 0.009 & -1.936 & 0.053 \\
\hline Karaaslan et al. (2008) & 0.440 & 0.353 & 0.125 & -0.252 & 1.132 & 1.246 & 0.213 \\
\hline Akoglu et al. (2006) & -0.144 & 0.462 & 0.214 & -1.050 & 0.762 & -0.311 & 0.755 \\
\hline Kaygusuz et al. (2003) & -0.103 & 0.386 & 0.149 & -0.860 & 0.654 & -0.267 & 0.789 \\
\hline & -0.230 & 0.216 & 0.047 & -0.653 & 0.193 & -1.067 & 0.286 \\
\hline
\end{tabular}

$\begin{array}{lllll}-2.00 & -1.00 & 0.00 & 1.00 & 2.00\end{array}$

Figure 6. Illustrates the forest plot for studies evaluating the onset of postoperative co-morbidity rate between groups receiving bupivacaine and normal saline during a tonsillectomy Weighted effect size is presented as boxes, $95 \%$ C.I are presented as whiskers. A negative effect represents a reduced incidence of postoperative morbidity for patients receiving bupivacaine during a tonsillectomy; a positive effect represents an increased incidence of postoperative morbidity for patients in the placebo group receiving normal saline during a tonsillectomy.

hydrochloride with normal saline during tonsillectomy and reported a significant reduction in the perceived level of pain from five hours post-surgery till the sixth day of follow-up. The authors also reported a substantial reduction in the onset of postoperative morbidities such as trismus, nausea, vomiting, and otalgia till the fourth day of follow-up post-tonsillectomy. Similarly, work by [35] too reported a significant reduction in the levels of post-tonsillectomy morbidities including halitosis, fever, nausea, vomiting, and otalgia for the group receiving bupivacaine hydrochloride as compared to the placebo group. The authors mentioned that the postoperative morbidities were significantly lower during the first, second and the fourth day of follow up. Moreover, the authors also confirmed a significant reduction in the perceived level of pain between bupivacaine and the normal saline group from five hours post-tonsillectomy until the sixth day of follow-up. Furthermore, the authors also included a comparison of the efficacy of bupivacaine with lidocaine and reported a significant reduction in post-tonsillectomy morbidities for the bupivacaine group. In the present meta-analysis, we too confirm these findings and report a large and significant effect size reduction in the perceived level of pain (Hedge's g: -1.47) in the group administered with bupivacaine posttonsillectomy as compared to the placebo group. We also reported a small effect size reduction in the onset of postoperative morbidities $(-0.23)$ in the bupivacaine group as compared to normal saline.
In addition to the postoperative morbidities, the use of bupivacaine in this present review was also found to reduce intraoperative complications associated with tonsillectomy. In the meta-analysis, we also observed large effect size reduction in the mean duration of tonsillectomy operation $(-1.35)$ with the application of bupivacaine as compared to normal saline. Published literature has established that a proportional relationship exists between the duration of an operative procedure and the amount of intraoperative blood loss $[58,59]$, which eventually precipitates postoperative morbidities and prolongs the prognostic outcomes of the operation. Considering the vascular organization of the tonsillar and the peri-tonsillar arch, during tonsillectomy collateral incisional damage to palatine, pharyngeal and tonsillar branch of the facial arteries are not uncommon [60]. These accidental incisions can eventually increase the amount of intraoperative hemorrhage and prolong the salvaging time during tonsillectomy and precipitate postoperative complications $[60,61]$. Thus, the application of Bupivacaine under such circumstances could act retrospectively on limiting the intraoperative blood loss, thereby, eventually reducing the onset of postoperative morbidities.

Finally, although not evaluated in our meta-analysis, the hematological outcome regarding hemoglobin was also reported to be substantially enhanced during tonsillectomy when bupivacaine was 
administered. A study included in our review reported an elevation in the level of hemoglobin in the pediatric population undergoing tonsillectomy with bupivacaine $(12.1 \pm 0.6 \mathrm{mg} / \mathrm{dL})$ as compared to the placebo group $(10.8 \pm 0.6 \mathrm{mg} / \mathrm{dL})$ [29]. The authors reported that on one hand, the preservation of hematological outcome proved the vasoconstrictive properties of bupivacaine while on the other hand it also provided a prophylactic benefit from intraoperative and postoperative hemorrhagic complications which often predisposes pediatric population towards blood transfusion [62].

Despite the novelty of this present meta-analysis, a few limitations persisted in this review. Firstly, registration of this systematic review was not performed in a prospective registry such as PROSPERO. This might raise questions concerning the validity of this review [63]. Secondly, we did not perform subgroup analyses based on the specific dosage of bupivacaine on the intraoperative and postoperative outcomes. These findings could have had an immense impact on developing efficient otolaryngologic care guidelines for an optimal choice of dosage of bupivacaine to reduce the onset of intraoperative and postoperative complications. We strongly recommend future studies to address this issue by performing meta regression-based analysis while comparing the influence of different dosages of bupivacaine during a tonsillectomy. Thirdly, due to the paucity of data, we were unable to evaluate the comparative efficacy of bupivacaine between adults and the pediatric population groups. The evaluation of a differential effect between adult and pediatric population is important for establishing best practice surgical and nursing care guidelines according to specific age groups. Similarly, due to the limited availability of data, we were not able to carry out analysis concerning the patient's wellbeing outcome i.e. patient comfort, quality of life. Therefore, we recommend future studies to address this paucity of data by evaluating the aforementioned variables and sharing their descriptive statistics in open access data repositories. Evaluation of these parameters would be extremely beneficial for developing robust decision-making models for otolaryngologists to select optimal interventions for achieving highquality care for their patients.

In conclusion, this systematic review and meta-analysis provide $\mathrm{a} 1 \mathrm{~b}$ level of evidence to support the use of bupivacaine during tonsillectomy to reduce the mean duration of the tonsillectomy procedure. Besides, the application of bupivacaine was also found to reduce the onset of postoperative pain and associated comorbidities. The findings from the current meta-analyses can have widespread implications for developing best practice otolaryngologic care guidelines for performing tonsillectomy operations.

\section{Reference}

1. Archer NM, Forbes PW, Dargie J, Manganella J, Licameli DR, et al. (2020) Association of Blood Type With Postsurgical Mucosal Bleeding in Pediatric Patients Undergoing Tonsillectomy With or Without Adenoidectomy. JAMA Netw Open 3: e201804. [Crossref]

2. Materia E, Di Domenicantonio R, Baglio G, Marchisio P, Perletti L, et al. (2004) Epidemiology of tonsillectomy and/or adenoidectomy in Italy. Pediatr Med Chir 26: 179-186. [Crossref]

3. Roushdy MMM, Abdel-Ghaffar HS, Mohammed MA, Khalifa AH (2020) Comparative study between the effect of Diclofenac and Ketorolac in post-tonsillectomy pain management. Egypt J Neck Surg Otorhinolaryngol 6: 43-53.

4. Di Luca M, Iannella G, Montevecchi F, Magliulo G, Cocuzza AVS, et al. (2020) Use of the transoral robotic surgery to treat patients with recurrent lingual tonsillitis. Int $J$ Med Robot 16: e2106.

5. Soaper AL, Richardson ZL, Chen JL, Gerber ME (2020) Pediatric tonsillectomy: A short-term and long-term comparison of intracapsular versus extracapsular techniques. Int J Pediatr Otorhinolaryngol 133: 109970. [Crossref]
6. Joseph M, Reardon E, Goodman M (1984) Lingual tonsillectomy: a treatment for inflammatory lesions of the lingual tonsil. Laryngoscope 94: 179-184. [Crossref]

7. Krishna P, Lee D (2001) Post-tonsillectomy bleeding: a meta-analysis. Laryngoscope 111: $1358-1361$

8. Broadman LM, Patel RI, Feldman BA, Sellman GL, Milmoe G, et al. (1989) The effects of peritonsillar infiltration on the reduction of intraoperative blood loss and posttonsillectomy pain in children. Laryngoscope 99: 578-581. [Crossref]

9. Teker AM, Korkut AY, Gedikli O, Kahya V (2009) Prospective, controlled clinical trial of Ankaferd Blood Stopper in children undergoing tonsillectomy. Int J Pediatr Otorhinolaryngol 73: 1742-1745. [Crossref]

10. Kargi E, Hoşnuter M, Babucçu O, Altunkaya H, Altinyazar C (2003) Effect of steroids on edema, ecchymosis, and intraoperative bleeding in rhinoplasty. Ann Plast Surg 51: 570-574. [Crossref]

11. Wohlgemuth PR, O'brien GR (1957) Postoperative edema in maxillofacial surgery; prevention and treatment with promethazine. Am J Surg 94: 537-541. [Crossref]

12. Xu F, Zeng W, Mao X, Fan GK (2008) The efficacy of melilotus extract in the management of postoperative ecchymosis and edema after simultaneous rhinoplasty and blepharoplasty. Aesthetic Plast Surg 32: 599-603. [Crossref]

13. Davidoss NH, Eikelboom R, Friedland PL, Santa Maria PL (2018) Wound healing after tonsillectomy - a review of the literature. J Laryngol Otol 132: 764-770. [Crossref]

14. Deutsch ES, Isaacson GC (1995) Tonsils and adenoids: an update. Pediatr Rev 16: 17-21.

15. Linden BE, Gross CW, Long TE, Lazar RH (1990) Morbidity in pediatric tonsillectomy. Laryngoscope 100: 120-124. [Crossref]

16. Odhagen E, Stalfors J, Sunnergren O (2019) Morbidity after pediatric tonsillotomy versus tonsillectomy: A population-based cohort study. Laryngoscope 129: 2619-2626. [Crossref]

17. Nikandish R, Maghsoodi B, Khademi S, Motazedian S, Kaboodkhani R (2008) Peritonsillar infiltration with bupivacaine and pethidine for relief of post-tonsillectomy pain: a randomised double-blind study. Anaesthesia 63: 20-25. [Crossref]

18. Sun J, Wu X, Meng Y, Jin L (2010) Bupivacaine versus normal saline for relief of postadenotonsillectomy pain in children: a meta-analysis. Int $J$ Pediatr Otorhinolaryngol 74: 369-373. [Crossref]

19. Furutani K, Ikoma M, Ishii H, Baba H, Kohno T (2010) Bupivacaine inhibits glutamatergic transmission in spinal dorsal horn neurons. Anesthesiology 112: 138143. [Crossref]

20. Paganelli MA, Popescu GK (2015) Actions of bupivacaine, a widely used local anesthetic, on NMDA receptor responses. $J$ Neurosci 35: 831-842. [Crossref]

21. Block L, Jörneberg P, Björklund U, Westerlund A, Biber B, et al. (2013) Ultralow concentrations of bupivacaine exert anti-inflammatory effects on inflammation-reactive astrocytes. Eur J Neurosci 38: 3669-3678. [Crossref]

22. Cassuto J, Sinclair R, Bonderovic M (2006) Anti-inflammatory properties of loca anesthetics and their present and potential clinical implications. Acta Anaesthesiol Scand 50: 265-282. [Crossref]

23. Anderson LA, Engel GM, Bruckner JD, Stoddard GJ, Peters CL (2009) Reduced blood loss after total knee arthroplasty with local injection of bupivacaine and epinephrine. $J$ Knee Surg 22: 130-136. [Crossref]

24. Metaxotos NG, Asplund O, Hayes M (1999) The efficacy of bupivacaine with adrenaline in reducing pain and bleeding associated with breast reduction: a prospective trial. $\mathrm{Br}$ Plast Surg 52: 290-293. [Crossref]

25. Kuthiala G, Chaudhary G (2011) Ropivacaine: A review of its pharmacology and clinical use. Indian J Anaesth 55: 104-110. [Crossref]

26. Polley LS, Columb MO, Naughton NN, Wagner DS, van de Ven CJ (1999) Relative analgesic potencies of ropivacaine and bupivacaine for epidural analgesia in labor: implications for therapeutic indexes. Anesthesiology 90: 944-950. [Crossref]

27. Spivey WH, McNamara RM, MacKenzie RS, Bhat S, Burdick WP (1987) A clinical comparison of lidocaine and bupivacaine. Ann Emerg Med 16: 752-757. [Crossref]

28. Abdel Raheem AG, Farouk ZM (2019) Effect of preincisional peritonsillar infiltration of bupivacaine on post-tonsillectomy pain. Egypt J Neck Surg Otorhinolaryngol 5: 40-46.

29. Ergil J, Akkaya T, Gozaydin O, Gunsoy B, Alicura S, et al. (2012) Vasoconstrictive and analgesic efficacy of locally infiltrated levobupivacaine in tonsillectomy patients. Int $J$ Pediatr Otorhinolaryngol 76: 1429-1433. [Crossref] 
30. Junaid M, Halim MS, Onali MAS, Qadeer S, Khan HU, et al. (2020) Intraoperative Use of Analgesics in Tonsillar Fossa and Postoperative Evaluation with Visual analogue Scale Scores-A Prospective, Randomized, Placebo-Controlled, Double-Blind Clinical Trial. Int Arch Otorhinolaryngol 24: e62-e67. [Crossref]

31. Ozkiriş M, Kapusuz Z, Saydam L (2012) Comparison of ropivacaine, bupivacaine and lidocaine in the management of post-tonsillectomy pain. Int J Pediatr Otorhinolaryngol 76: 1831-1834. [Crossref]

32. Karaaslan K, Yilmaz F, Gulcu N, Sarpkaya A, Colak C, et al. (2008) The effects of levobupivacaine versus levobupivacaine plus magnesium infiltration on postoperative analgesia and laryngospasm in pediatric tonsillectomy patients. Int $J$ Pediatr Otorhinolaryngol 7: 675-681. [Crossref]

33. Yuan CC, Yu DY, Jun TS, Quan CR (1984) Guillotine tonsillectomy without anesthesia. Auris Nasus Larynx 11: 29-35. [Crossref]

34. Haksever M, Özmen S, Akduman D, Solmaz F (2014) Topical bupivacaine compared to bupivacaine infiltration for post-tonsillectomy pain relief in children: a prospective randomized controlled clinical study. Eur Arch Otorhinolaryngol 271: 2555-2559. [Crossref]

35. Ozmen OA, Ozmen S (2011) Topical bupivacaine compared to lidocaine with epinephrine for post-tonsillectomy pain relief in children: a randomized controlled study. Int J Pediatr Otorhinolaryngol 75: 77-80. [Crossref]

36. Tuhanioglu B, Erkan SO (2018) Tonsillectomy pain control with IV dexamethasone, infiltrated dexamethasone and infiltrated bupivacaine; a randomised, double-blind, placebo controlled, prospective clinical trial. J Pak Med Assoc 68: 1002-1008. [Crossref]

37. Moher D, Liberati A, Tetzlaff J, Altman DG, PRISMA Group (2009) Preferred reporting items for systematic reviews and meta-analyses: the PRISMA statement. PLoS Med 6: e1000097. [Crossref]

38. Jørgensen L, Paludan-Müller AS, Laursen DRT, Savović J, Boutron S, et al. (2016) Evaluation of the Cochrane tool for assessing risk of bias in randomized clinical trials: overview of published comments and analysis of user practice in Cochrane and nonCochrane reviews. Syst Rev 5: 80. [Crossref]

39. Viswanathan M, Ansari MT, Berkman ND, Chang S, Hartling L, et al. (2008) Assessing the Risk of Bias of Individual Studies in Systematic Reviews of Health Care Interventions. Methods Guide for Effectiveness and Comparative Effectiveness Reviews. [Crossref]

40. Burns PB, Rohrich RJ, Chung KC (2011) The Levels of Evidence and their role in Evidence-Based Medicine. Plast Reconstr Surg 128: 305-310. [Crossref]

41. Bax L, Yu L-M, Ikeda N, Moons KG (2007) A systematic comparison of software dedicated to meta-analysis of causal studies. BMC Med Res Methodol 7: 40. [Crossref]

42. Higgins JPT, Thompson SG, Spiegelhalter DJ (2009) A re-evaluation of random-effects meta-analysis. J R Stat Soc Ser A Stat Soc 172: 137-159. [Crossref]

43. Rosenthal R (1994) Parametric measures of effect size. The Handbook of Research Synthesis. Russell Sage Foundation. pp: 231-244.

44. Higgins JPT, Thompson SG (2002) Quantifying heterogeneity in a meta-analysis. Stat Med 21: 1539-1558. [Crossref]

45. Petitti DB (2001) Approaches to heterogeneity in meta-analysis. Stat Med 20: 36253633. [Crossref]
46. Duval S, Tweedie R (2000) Trim and fill: A simple funnel-plot-based method of testing and adjusting for publication bias in meta-analysis. Biometrics 56: 455-463. [Crossref]

47. Akoglu E, Akkurt BCO, Inanoglu K, Okuyucu S, Dagli S (2006) Ropivacaine compared to bupivacaine for post-tonsillectomy pain relief in children: A randomized controlled study. Int J Pediatr Otorhinolaryngol 70: 1169-1173. [Crossref]

48. Jebeles JA, Reilly JS, Gutierrez JF, Bradley EL, Kissin I (1991) The effect of preincisional infiltration of tonsils with bupivacaine on the pain following tonsillectomy under general anesthesia. Pain 47: 305-308. [Crossref]

49. Johansen M, Harbo G, Illum P (1996) Preincisional infiltration with bupivacaine in tonsillectomy. Arch Otolaryngol Head Neck Surg 122: 261-263. [Crossref]

50. Kaygusuz I, Susaman N (2003) The effects of dexamethasone, bupivacaine and topical lidocaine spray on pain after tonsillectomy. Int J Pediatr Otorhinolaryngol 67: 737 742. [Crossref]

51. Stuart JC, MacGregor FB, Cairns CS, Chandrachud HR (1994) Peritonsillar infiltration with bupivacaine for paediatric tonsillectomy. Anaesth Intensive Care 22: 679-682. [Crossref]

52. Unal Y, Pampal K, Korkmaz S, Arslan M, Zengin A, et al. (2007) Comparison of bupivacaine and ropivacaine on postoperative pain after tonsillectomy in paediatric patients. Int J Pediatr Otorhinolaryngol 71: 83-87. [Crossref]

53. Bangera A (2017) Anaesthesia for adenotonsillectomy: An update. Indian J Anaesth 61: 103-109. [Crossref]

54. Verma R, Verma RR, Verma RR (2017) Tonsillectomy-Comparative Study of Various Techniques and Changing Trend. Indian J Otolaryngol Head Neck Surg 69: 549-558. [Crossref]

55. Babst CR, Gilling BN (1978) Bupivacaine: a review. Anesth Prog 25: 87-91. [Crossref]

56. Iida H, Watanabe $Y$, Dohi S, Ishiyama T (1997) Direct effects of ropivacaine and bupivacaine on spinal pial vessels in canine. Assessment with closed spinal window technique. Anesthesiology 87: 75-81. [Crossref]

57. Newton DJ, McLeod GA, Khan F, Belch JJF (2005) Vasoactive characteristics of bupivacaine and levobupivacaine with and without adjuvant epinephrine in peripheral human skin. Br J Anaesth 94: 662-667. [Crossref]

58. Prasad KC, Prasad SC (2011) Assessment of Operative Blood Loss and the Factors Affecting it in Tonsillectomy and Adenotonsillectomy. Indian J Otolaryngol Head Neck Surg 63: 343-348. [Crossref]

59. Yu CN, Chow TK, Kwan AS, Wong SL, Fung SC (2000) Intra-operative blood loss and operating time in orthognathic surgery using induced hypotensive general anaesthesia: prospective study. Hong Kong Med J 6: 307-311. [Crossref]

60. Nosulia EV (2014) Peculiarities of blood supply of palatal tonsils and the potential risk of hemorrhage during tonsillectomy: the literature review and case report. Vestn Otorinolaringol: 75-78. [Crossref]

61. Liu JH, Anderson KE, Willging JP, Myer $3^{\text {rd }}$ CM, Shott SR, et al. (2001) Posttonsillectomy hemorrhage: what is it and what should be recorded? Arch Otolaryngol Head Neck Surg 127: 1271-1275. [Crossref]

62. Mutz I, Simon H (1993) Hemorrhagic complications after tonsillectomy and adenoidectomy. Experiences with 7,743 operations in 14 years. Wien Klin Wochenschr 105: 520-522. [Crossref]

63. PLoS Medicine Editors (2011) Best practice in systematic reviews: the importance of protocols and registration. PLoS Med 8: e1001009. [Crossref]

Copyright: (C2020 Wang J. This is an open-access article distributed under the terms of the Creative Commons Attribution License, which permits unrestricted use, distribution, and reproduction in any medium, provided the original author and source are credited. 